DOI https://doi.org/10.30525/978-9934-26-113-8-16

\title{
TYPE 2 DIABETES MELLITUS AFTER COVID-19: POSSIBLE DIRECTIONS FOR CORRECTION OF HYPOGLYCEMIC THERAPY
}

\author{
Tyshchenko I. V. \\ Candidate of Medical Sciences, Associate Professor, \\ Associate Professor at the Department of Endocrinology \\ Dnipro State Medical University \\ Chursinova T. V. \\ Candidate of Medical Sciences, \\ Assistant at the Department of Endocrinology \\ Dnipro State Medical University \\ Dnipro, Ukraine
}

The purpose: to analyze possible ways to achieve compensation of carbohydrate metabolism in patients with type 2 Diabetes mellitus (DM) who have had COVID-19.

Materials and methods. The study included 17 patients with type 2 diabetes aged 50 to 68 years (mean age $55.9 \pm 1.84$ years), who underwent moderate COVID-19, complicated by bilateral polysegmental pneumonia and decompensation of diabetes with level of glycosylated hemoglobin (HbA1c) more than $10,0 \%$. During inpatient treatment for COVID-19, patients, along with other drugs according to the protocol, received the glucocorticoid drug dexamethasone from 4 to $12 \mathrm{mg}$ intravenous for 5 to 14 days, as well as basalbolus insulin therapy was initiated. As basal insulin was prescribed insulin Glargin or Protafan ${ }^{\circledR}$ HM, as prandial insulin - Actrapid® HM or Novorapid. Daily doses of insulin ranged from 32 to 46 IU per day ( 0.3 to $0.5 \mathrm{IU} / \mathrm{kg}$ ). The studied patients before the COVID-19 infection onset received oral hypoglycemic therapy - metformin, sodium-glucose cotransporter 2 inhibitors, sulfonylurea derivatives. Since discharge from the hospital to inclusion for further observation 5 to 20 days have passed. At the stage of post-hospital observation and treatment of patients, body weight was measured, fasting blood glucose and postprandial glycemia levels in capillary blood as selfcontrol, HbAlc levels were studied, and hypoglycemic therapy was corrected. All patients at the time of examination had blood oxygen saturation in the range of $94-97 \%$. 
The results. For the first 4 weeks of the follow-up during the correction of antidiabetic therapy, all patients were added metformin with an initial dose of $1000 \mathrm{mg}$ per day with a gradual further increasing up to $2000-2500 \mathrm{mg}$ per day. Doses of prandial insulin were reduced, that was discontinued in 8 patients during the first 4 weeks of the follow-up. In other patients, the number of prandial insulin injections was reduced to 1-2 before main meals, and the dose was reduced to 4-5 IU per intake (depending on the insulin-to-carbohydrate ratio).

In week 5 of the follow-up, it was found that 8 patients reached the target values of glycemia on the background of basal insulin and metformin. These patients formed the first group and they continued such treatment. But 9 patients (group 2) did not reach the satisfactory glycemic control. These patients were recommended the intensification of therapy - the fixed combination of long-acting insulin Glargine $100 \mathrm{IU} / \mathrm{ml}$ and a glucagon-like peptide-1 receptor agonist lixisenatide $50 \mu \mathrm{g} / \mathrm{ml}$ (Soliqua SoloStar) in combination with metformin. From the start of treatment with Soliqua, previous prandial and basal insulins were discontinued; the initial daily dose of Soliqua was $20 \%$ less than the previous dose of basal insulin. Soliqua titration was performed once a week, the dose was increased by 2-4 IU depending on the level of fasting blood glucose. The studied indicators of glycemic control and body weight of patients (weeks 5 and 13 of the follow-up) are presented in table 1 .

Table 1

The studied parameters in weeks 5 and 13 of observation

\begin{tabular}{|c|c|c|c|c|c|c|}
\hline \multirow[b]{2}{*}{ Parameters } & \multicolumn{2}{|c|}{ Group 1, n=8 } & \multirow[b]{2}{*}{$\begin{array}{c}P \\
\text { value }\end{array}$} & \multicolumn{2}{|c|}{ Group 2, n=9 } & \multirow[b]{2}{*}{$P$ value } \\
\hline & $\begin{array}{c}\text { week } 5 \text { of } \\
\text { observation }\end{array}$ & $\begin{array}{l}\text { week } 13 \text { of } \\
\text { observation }\end{array}$ & & $\begin{array}{c}\text { week } 5 \text { of } \\
\text { observation }\end{array}$ & $\begin{array}{l}\text { week } 13 \text { of } \\
\text { observation }\end{array}$ & \\
\hline $\begin{array}{c}\text { Fasting } \\
\text { capillary } \\
\text { blood glucose, } \\
\text { mmol/l }\end{array}$ & $6,44 \pm 0,29$ & $6,27 \pm 0,25$ & 0,66 & $10,30 \pm 0,47$ & $7,16 \pm 0,37$ & $0,0001 *$ \\
\hline $\begin{array}{c}\text { Postprandial } \\
\text { capillary } \\
\text { blood glucose, } \\
\text { mmol/l }\end{array}$ & $8,14 \pm 0,58$ & $7,11 \pm 0,43$ & 0,18 & $13,10 \pm 0,52$ & $9,60 \pm 0,36$ & $0,0001 *$ \\
\hline HbA1c, \% & $8,20 \pm 0,24$ & $7,80 \pm 0,21$ & 0,23 & $10,29 \pm 0,35$ & $8,47 \pm 0,24$ & $0,001 *$ \\
\hline $\begin{array}{c}\text { Average body } \\
\text { weight, } \mathrm{kg}\end{array}$ & $87,40 \pm 2,3$ & $90,73 \pm 2,53$ & 0,35 & $88,67 \pm 1,97$ & $89,39 \pm 1,92$ & 0,797 \\
\hline
\end{tabular}

$* P<0,05-$ statistically significant differences 
As shown in table 1, in week 13 of the follow-up, patients in group 1 who received metformin and basal insulin maintained fasting and postprandial glycemic targets, with a mean $\mathrm{HbAlc}$ level of 7,8 $\pm 0,21 \%$. Hypoglycemic states and other complications were not observed in these patients during the follow-up period. Patients of group 2 in week 13 of observation were discovered to have significant decrease of fasting glycemia (mean level 7,16 \pm $0,37 \mathrm{mmol} / \mathrm{l}, \mathrm{p}=0,0001$ ) and postprandial glycemia (mean level 9,60 $\pm 0,36$ $\mathrm{mmol} / \mathrm{l}, \mathrm{p}=0,0001)$. Group 2 patients also showed the significant decrease in $\mathrm{HbA1c}$ level, on average to $8,47 \pm 0,24 \%(\mathrm{p}=0,001)$. The use of Soliqua was not accompanied by the development of hypoglycemic states; only one patient from group 2 developed nausea, which did not allow to continue dose titration.

In most patients of both groups, there was a slight increase in body weight throughout the observation period. Most probably it is linked with previous loss of weight during the COVID-19 illness. At the same time, group 1 patients, who were taking basal insulin and metformin, gained a bit more weight at the amount of $1-3 \mathrm{~kg}$ (mean 2,17 $\pm 0,4 \mathrm{~kg}$ ). 3 patients of group $2 \mathrm{had}$ their weight unchanged during the whole follow-up period, while the rest gained from 0,5 to $2 \mathrm{~kg}$ (mean 1,25 $\pm 0,25 \mathrm{~kg}$ ). These changes in body weight were not statistically significant.

We also analyzed HbAlc levels that patients measured from 1 to 4 months prior to the Covid-19 infection onset and duration of Diabetes according to the patients' medical history. It was found that in patients of group 1, who reached their glycemic targets faster, the average HbA1c level before Covid-19 was significantly lower, than in patients of group $2(\mathrm{p}=0,021)$. Patients of group 1 also had a significantly shorter duration of Diabetes mellitus $(\mathrm{p}=0,008)($ table 2$)$.

Table 2

HbA1c level and mean Diabetes duration in both groups of patients

\begin{tabular}{|c|c|c|c|}
\hline Parameters & Group 1, n=8 & Group 2, n=9 & P value \\
\hline $\begin{array}{c}\text { HbA1c prior to COVID- } \\
\text { 19 onset, \% }\end{array}$ & $7,96 \pm 0,25$ & $9,03 \pm 0,33$ & $0,021^{*}$ \\
\hline $\begin{array}{c}\text { Mean duration of diabetes } \\
\text { mellitus, years }\end{array}$ & $5,13 \pm 0,64$ & $8,56 \pm 0,93$ & $0,008^{*}$ \\
\hline
\end{tabular}

$* P<0,05$ - statistically significant differences

All patients are currently continuing prescribed treatment under medical supervision and glycemic control.

Conclusions. Changes in carbohydrate metabolism due to coronavirus infection COVID-19 with glucocorticoid treatment in patients with type 2 
Diabetes require mandatory correction of antidiabetic therapy. This is an important task at the stage of convalescence, when the patients have a stable condition and sufficient level of blood oxygen saturation.

The first step in adjusting therapy may be to cancel or reduce the dose of prandial insulin and to add metformin to the treatment regimen under the control of fasting and postprandial glycemic levels. If patient status needs to intensify therapy, the second step may be the use of the fixed combination of insulin glargine and lixisenatide (Soliqua Solostar) in combination with metformin. Both options of hypoglycemic therapy are quite effective, well tolerated by patients and can be used according to the individual indications.

The use of the combination of Soliqua SoloStar and metformin can lead to significant decrease of glycosylated hemoglobin level in patients with poor glycemic control in the previous stage of treatment.

The duration of Diabetes and glycemic control before the Covid-19 onset can affect the time of reaching targets of glycemic control at the period of convalescence.

DOI https://doi.org/10.30525/978-9934-26-113-8-17

\title{
КЛІНІЧНІ ОЗНАКИ ТА ПАТОГЕНЕТИЧНІ ЧИННИКИ ПОСТКОВІДНОГО КОЛІТУ
}

\author{
Томашкевич Г. I. \\ кандидат медичних наук, \\ дочент кафедри пропедевтики внутрішньої медицини \\ Вінницький національний медичний університет імені М. І. Пирогова \\ Ошарова А. М. \\ студентка \\ Вінниџький національний медичний університет імені М. І. Пирогова \\ м. Вінниця, Україна
}

Актуальність. Шлунково-кишкові симптоми Covid-19: нудота, блювання, відсутність апетиту, діарея, можуть виникати до появи пірексії, респіраторних симптомів чи одночасно 3 ними. Результати досліджень [2, с. 3] демонструють наявність вірусної РНК у калі або анальних/ректальних мазках пацієнтів з Covid-19. 39 (53,4\%) пацієнтів Covid-19 мали позитивні результати на SARS-CoV-2 PHK в калі, тривалістю від 1 до 12 днів. Попередне дослідження SARS-CoV 